\title{
COMPETITIVENESS AND CONVERGENCE OF CZECH REGIONS: PERSISTENCE OF DISCREPANCIES
}

\author{
David Martinčík, Marta Šlehoferová
}

\section{Introduction}

Regional competitiveness is one of the current topics dealt with in works of many authors. It was brought into focus after the accession of the Czech Republic to the European Union, namely due to the possibility of drawing money from EU funds for regional development. These finances are used to increase the competitiveness of regions and decrease regional disparities caused by various factors. In the Czech Republic the regional policy is practiced by the Ministry of Regional Development, which is trying to reduce these differences among regions, while also taking into consideration the regional policy of the European Union and its goals. In order to practice any kind of policy, an initial condition must always be known, which, regarding the regional policy conception, means to know the position of regions in terms of their competitiveness. The aim of this work is to quantify the competitiveness of individual regions in the Czech Republic and to analyze their development over time by means of the convergence analysis of used metrics of regional competitiveness.

The first part of this work deals with the definition of "regional competitiveness" and introduces various methods of its quantification. This is followed by the general analysis of regional competitiveness (NUTS 3 ) according to the chosen method and comparison of development of regions in the course of time or with the development in the Czech Republic. Although this analysis is limited by the data available, it was made on the basis of 4,284 values of different indicators representing all regions in the Czech Republic in time series of 17 seasons (periods). The second part of this work evaluates the position of individual regions on the basis of results of the general analysis in terms of dynamics and level and then the rankings of individual regions are compiled. The last part focuses on the question of $\beta$ - and $\sigma$-convergences of regions in the Czech Republic in the course of time. All the computations have been made using MATLAB.

\section{Regional Competitiveness}

When trying to understand the general meaning of the word "competitiveness", we may find an infinite number of definitions relating to various situations and subjects. However, the question is how to define competitiveness related to regions.

"The concept of competitiveness, however, while relatively clear when applied to enterprises, is more difficult to define and measure, when applied to regions or countries" [12, p. 75]. That is the basic problem. It is obvious how to assess the competitiveness of enterprises, but it is not very evident how to assess competitiveness in case of regions.

Before defining regional competitiveness, it is necessary to realize what makes regions strive for being competitive. If an enterprise is competitive, it achieves heavy sales and in case of effective behavior also the profit. A competitive region will not reach such sales, but it will probably become more attractive for inhabitants. As the competitive region offers its citizens good living conditions, they do not deem necessary to change their residence. Moreover, the standard of living in the region may attract new inhabitants. On the contrary, if the region ceases to be competitive, its inhabitants begin to move to another, more attractive region. On the other hand, it is also 
necessary to realize that it is difficult for a region to become competitive without a sufficient number of inhabitants. It is necessary to point out that inhabitants in the Czech Republic are not yet used to changing their address when the living conditions worsen, therefore "moving for the better conditions" does not occur to such an extent as in other countries, where the labor migration and buying a house on the other side of the country is very common.

The concept of competitiveness is often perceived as the ability of a country/region to generate long-term welfare of its inhabitants. Aiginger [1] distinguishes between welfare and competitiveness, as the economic side of welfare. However, most definitions of regional competitiveness are not directly concerned with the issue of population. Kiston et al. define regional and municipal competitiveness at first very vaguely as "the success with which regions and cities compete with one another in some way" [21, p. 992], without specifying for or in what regions should compete. Basically, they just give the definition of regional competitiveness formulated by Storper: "The ability of an (urban) economy to attract and maintain firms with stable or rising market shares in an activity while maintaining or increasing standards of living for those who participate in it" [35, p. 20]. At the end of their paper Kiston et al. also put the following more concrete definition forward: "Ultimately competitive regions and cities are places where both companies and people want to locate and invest in" [21, p. 997].

The concept of regional competiveness as aggregate firms' competitiveness can be based on Porter's diamond [27]. The diamond consists of six cusps: factor conditions (supply of factors of production), demand conditions (especially domestic consumers' demand), related and supporting industries (labor division and exchange of ideas and innovations), firms' strategy, structure and rivalry (a force for increasing productivity and innovations), government (as a catalyst and a challenger to increase the competitive performance) and the last one is chance (a stochastic element which is always present in market economy). Some of the cusps are measurable in an objective way, while some of them are not. However, the main problem of this concept is that it assumes firms and regions have the same priorities. It is evidently false, e.g. as far as employment is concerned if there is a drift of firms towards effectiveness, the unemployment regional rate can increase.

The controversial nature of competitiveness of economies and regions is illustrated by the discussion from the mid-1990s, which was initiated by the Paul Krugman's article in Foreign Affairs called Competitiveness: A Dangerous Obsession [23], where he criticizes the practical economic policy resulting from the idea that nations (national economies) compete among themselves and thus gain at the expense of others and states that '... 'competitiveness' would turn out to be a funny way of saying 'productivity' and would have nothing to do with international competition" [23, p. 32]. For that matter, the importance of competitiveness as productivity can be found in earlier Krugman's works: "Productivity isn't everything, but in the long run it is almost everything. A country's ability to improve its standard of living over time depends almost entirely on its ability to raise its output per worker." [22, p. 11].

Immediately, several reactions [8], [29], [30], [34], [39] and also the Krugman's answer [24] were published in the following issue of Foreign Affairs (July/August). The subsequent debate resulted in publication of a great deal of articles. "Popularity" of this issue is illustrated by the monothematic issue of Oxford Review of Economic Policy from September 1996.

Since this academic discussion, productivity is often included into the definition of competiveness. An interesting understanding of regional competitiveness as "the ability to increase the employment rate, diversify production, increase productivity and the value added at an appropriate rate so that business relationships can develop in a stable way" $[5$, p. 22] has also been offered. The author stresses the need for diversification of production, which is very well-founded. If the region was focused only on a particular industry or sector, significant changes in technology or preferences could affect the region to a great extent and it could lose its competitiveness for a long time. It is also necessary to realize that the competitiveness of regions, cities or countries is fundamentally different from the competitiveness of enterprises. If a company does not stack up to the competition, it will go bankrupt. However, an analogous way of 


\section{Ekonomie}

winding-up and dissolution of regions (countries) due to the lack of their competitiveness does not exist.

Gardiner et al. offers another definition [14]. He says that "regional (and urban) competitiveness has to do with the success with which regions and cities compete with one another over shares of national and especially global export markets" [14, p. 3]. The definition of regional competitiveness as "our ability to produce goods and services that meet the test of international competition while our citizens enjoy a standard of living that is both rising and sustainable," [41, p. 1] given by Laura D' Andrea Tyson, the Chair of Council of Economic Advisors to US president Clinton, is very popular. Tyson's definition is used by a lot of authors, as for the Czech articles it can also be found in e.g. Staníčková et al. [33], who view competitiveness (of countries) as the ability to produce goods and services which can successfully face international competition and bring a higher and sustainable living standard to its inhabitants. They also state that "a synonym for competitiveness in terms of causes is productivity and in terms of consequences a rising living standard and employment in the given area" [33, p. 116]. Also Porter and Ketels [28] understand competitiveness as productivity. They state that to understand competitiveness it is important to know the sources of nation's (regional) prosperity and that "a nation's standard of living is determined by the productivity of its economy, which is measured by the value of goods and services produced per unit of the nation's human, capital and natural resources" [28, p. 7]. Then productivity depends on the efficiency with which products and services can be produced and their value (measured by their prices). "True competitiveness then, is measured by productivity" [28, p. 7], which allows a nation (region) to support a high standard of living.

A new perspective on this issue has been brought by Boschma [7], who deals with the subject of regional growth and claims that "regional growth is based primarily on exploiting intangible assets such as tacit knowledge and institutions, rather than static cost advantages" [7, p. 2]. He also stresses that a related variety of these assets can be the main reason for the development of regional disparities. The Skokan's approach, which can be found in the Czech literature, is also interesting, since it emphasizes the importance of ability to innovate, especially in the context of business environment where there is a strong stimulation for learning and cooperation among firms, in other words, for forming the so-called business clusters [31].

This article views the concept of regional competitiveness as the ability of regions to compete with each other, but not only in the area of economy, but also in other areas such as living conditions or the region's potential for growth in future. Someone might argue that if a region is successful in the area of economy, it is subsequently successful in the other two areas, but, for example, there could be a region with a similar level of GDP, yet different environment or public services. Thus the concept of regional competitiveness should not mean only "productivity" as some authors claim, but it should also include other areas.

However, the following text does not intend to deal with the definitions of competitiveness, or misuse of this concept for selective economic and political measures, but it will focus only on the evaluation of the state of the Czech regions and the subsequent data analysis.

\section{Measurement Methods of Competitiveness}

As stated in the report of the European Commission, it is not easy to objectively measure the competitiveness of different regions. "An industrial region, for example, is not directly competing with a predominantly agricultural region or a financial center, so the measurement of its relative competitiveness is problematic" [12, p. 75]. For example, to avoid favoritism of the regions with more developed industry in comparison to the ones with better air, the indicators from different areas should be selected for the measurement of the competitiveness. It is obvious that to quantify the competitiveness of regions is not a simple matter and a universally accepted method has not been established yet. However, the efforts to measure competitiveness are really current and this issue has been covered by many authors in their research. Besides, it is also topical because regions are the bearers of national competitiveness. Their importance has arisen together with the creation of global 
economy [17] and they can be understood as integration units, which constitute an overall national competitiveness [26]. Trying to measure the regional competitiveness, we can primarily base our measurement on methods that are used to evaluate competitiveness of the entire economy. Kaderábková [19] also deals with this issue in her research. She assesses the competitiveness of the Czech Republic according to four key aspects: macroeconomic performance and stability, institutional quality, innovative performance and quality of human resources. Other authors very often base their measurement of regional competitiveness on similar aspects.

Kahoun [20] measures regional competitiveness on the basis of the development of several indicators, which he divides into three areas. These are areas of macroeconomic performance, innovation efficiency and quality of life. Macroeconomic performance includes GDP, unemployment rate and gross fixed capital. The second area includes indicators of science and research, foreign direct investment, added value in technology-intensive sectors (all expressed per capita), qualification of the population and employment status. The quality of life area includes migration of population, air quality, crime rate and life expectancy. Then the author examines development of these indicators over time (by their year-on-year growth, growth in a particular period, etc.) and compares them with the level of the Czech Republic. At the end of his work the author compares the level and dynamics of the regions in individual areas and then compiles the overall rankings of the regions. This is a very logical and transparent method, which is unfortunately limited by the available regional data. In the area of macroeconomic performance the author works with time series including years 1995-2005, in the remaining two areas he uses the data from the 2000-2005 period, which means that a complete comparison over time can only be made for the years 2000-2005, which is a relatively short time series.

Another method is offered by Kadeřábková [18], who assesses regions according to the data from 2004, while using an index of regional competitiveness in terms of economic performance, development of regional innovation system and quality of life. Each area is comprised of certain indicators (unlike Kahoun she includes foreign direct investment in the area of economic performance and not in the area of innovation). The indicators are compiled in a similar way as in the previous work. For subsequent comparison, the averages for each area are calculated. These are then converted to per cents (or more precisely sub-indices), expressing "how many per cents of regions have a worse position according to that indicator" [18, p. 49]. The author then averages all the areas and gets the overall position of regions in a given year. Martinčík [25] introduces a method of evaluation of the regional competitiveness based on 18 indicators representing different areas that reflect the position of a region as broadly as possible. These indicators are compiled from commonly available data published by the Czech Statistical Office and may be grouped into three basic areas, namely the area of macroeconomic performance (also marked as MP), growth potential (GP) and quality of life $(Q L)$. In each area there are seven indicators, with three of them being in two areas at the same time and representing a transition between the involved areas. This method is based on an analogy to the magic quadrangle used to assess the status of entire national economies. Afterwards, the values of individual indicators in the time series are compared with either the national average or with the values of first year. The analysis is performed using only the data from 1995 and the 2000-2005 period. Slaný et al. [32] measure regional competitiveness according to the development of absolute values of regional gross domestic product per capita, average gross wages, unemployment rate, education index and migration of population. The results then divide the regions into the following categories: above-average, average, below-average, and very below-average. The authors evaluated the regions for the 1995-2004 period, but unfortunately only by a text and a few illustrative graphs, thus without tables showing values in the years that could provide the most important and most comprehensive information. A similar approach is used by Gardiner et al. [14], who claim that productivity and employment rate are the two main measures of regional competitiveness. Thus, if the region is successful, it has a high level of GDP per capita. They break down this indicator into four elements: productivity (measured as the GDP per hour worked), the 


\section{Ekonomie}

employment rate, the dependency rate, and the work-leisure trade off. This indicator is further used to quantify regional competitiveness in the countries of the EU. For more details see [14].

A very complex competitiveness measurement can be found in [3] and [2], where the Regional Competitiveness Index at the NUTS2 regional level for all EU member countries is calculated. They take into account 11 areas (the so-called pillars), such as institutions, macroeconomic stability, infrastructure, health, quality of primary and secondary education, higher education/training and lifelong learning, labor market efficiency, market size, technological readiness, business sophistication and innovation. For each pillar, there are several indicators which are quantitative and their source is mostly Eurostat. These data are subsequently standardized (using z-scores) and analyzed in more detail, pillar by pillar, using statistical tools. Sub-score for each pillar is then calculated and the final regional competitiveness index is aggregated.

The previous works are based on the same principles; the authors provide some parameters whose values are then compared. Viturka's work [42] is different in principle. Although the author provides three basic areas and evaluates regions according to them, he does not evaluate the development of these indicators over time or by the level of the Czech Republic, but according to his own methods and only for a particular year. These areas are quality of business environment, use of human resources and innovative potential of firms. The quality of business environment is then composed of factors that have a specific weight (an example of factors: availability of labor, quality of labor, price of labor, workforce flexibility). The innovative potential of firms is defined as "the aggregate expression of the level achieved by the innovative activities of companies located in the region" [42, p. 642] and the basic indicator of the use of human resources is the unemployment rate. The regions are then compared with each other in different areas and generally evaluated. The method is conceptually different from the previous ones; however, it seems to be less clear for practical use.

The methods above offer interesting ways of how to evaluate and measure competitiveness. However, some of them evaluate regions only within one year, by a few indicators or using intermittent or short time series. It is also evident that the authors are occasionally forced to replace some indicators by the less appropriate ones just because of a lack of regional data for the years. But quantification of competitiveness should be based on a large number of indicators and on the longest continuous time series as possible. Only this way it can have the information value as for the evaluation of development of individual regions.

\section{Research Methods}

Quantification and evaluation of regional competitiveness will be based on the method proposed by Martinčík [25]. This method is most appropriate because it takes into account the different characteristics of regions, not only mostly proposed macroeconomic indicators (or indicators of productivity), but also indicators that represent areas of quality of life and growth potential of individual regions. The measurement of competitiveness used in this method is comprehensive and includes not only economic but also socio-economic characteristics of regions. And in case of creating continuous time series (the author used only data for the year 1995 and the 2000-2005 period), it could be a useful tool for a comprehensive evaluation of the regional competitiveness. First it was necessary to add values of 18 indicators (divided into three areas: macroeconomic performance - also marked as MP, growth potential - GP and quality of life $-Q L$ ) in the studied year. These indicators are shown in Table 1.

Indicators are formed at the NUTS 3 regional level for all regions in the Czech Republic: Prague, Jihočeský, Jihomoravský, Karlovarský, Královéhradecký, Liberecký, Moravskoslezský, Olomoucký, Pardubický, Plzeňský, Středočeský, Ústecký, Vysočina, and Zlínský regions.

Indicators are not formed as absolute, but relative to the number of the population (or to the area of the region in case of indicator QL2), and therefore it is possible to compare them not only over time but also with each other. Indicators are also formed for the whole Czech Republic (CZ) and for the Czech Republic without Prague (CZ-P). To describe the construction of indicators see [25]. Most necessary data can be obtained with relative ease. The data previously unavailable due to 


\begin{tabular}{l|c} 
Name of indicator & designation \\
\hline Completed dwellings per capita & QL7-MP1 \\
\hline Real net disposable income per capita & MP2 \\
\hline Average gross wage & MP3 \\
\hline Unemployment rate & MP4 \\
\hline Real GDP per capita & MP5 \\
\hline Real gross value added per capita & MP6 \\
\hline Real gross fixed capital formation per capita & GP7-GP1 \\
\hline Number of businesses per capita & GP3 \\
\hline Structure of employment & GP4 \\
\hline Number of university students per capita & GP5 \\
\hline Live births per capita & GP6 \\
\hline Age structure & GP7-QL1 \\
\hline Average incapacity for work due to sickness & QL2 \\
\hline Environmental pollution & QL3 \\
\hline Number of crimes per capita & QL4 \\
\hline Number of cultural facilities for residents & QL5 \\
\hline Number of physicians per capita & QL6 \\
\hline Registered passenger cars per capita & \\
\hline
\end{tabular}

Source: [25]

changes in the monitoring methodology are completely available today, but new problems arise, such as ending the monitoring of some indicators by the Czech Statistical Office (for example the number of cinemas, theatres and museums, which was originally used in the indicator QL4 - this indicator is currently composed only of the number of libraries) or the change of methodology used to track the number of university students. Data for the years 1993 and 1994 cannot be obtained and therefore they are not used. Thus, the quantification was made for the years 1995-2011, which in the measurement of regional competitiveness in the Czech Republic is considered as a very long time series containing a large amount of values. None of the above-mentioned authors evaluates regional competitiveness on the basis of such an extensive amount of data. We consider this great deal of data to be a great advantage and we will not reduce the number of monitored indicators by e.g. the factor analysis as Žižka [43] in case of municipalities' data. After all, it would be unsuitable for our further computation.

\section{Evaluation of the Overall Ranking of Regions}

For further calculations it is necessary to establish indicators of the level and dynamics. The individual values of 18 indicators are always related to some basic datum whose value is $100 \%$ and other values are expressed as a percentage of this datum. Basic values may be values of indicators in a given year (here in 1995) or the value of a certain region ( $C Z$ or CZ-P). According to the fact whether the values exceed or fail to reach these basic values, it can be deduced how competitive those regions are. However, in these calculations it is necessary to take into account the "negative" indicators (for example unemployment), for which it is true that the higher values are reached, the worse rank the region has. In these cases, the reciprocal value of given indicators is used. 


\section{Ekonomie}

The comparison with the average of the Czech Republic is presented in Table 2, which shows the values of indicators in the years 1995 and 2011 and their order in those years. These results can be easily compared with [36], where only 8 indicators were used. The grey area in 2011 shows a deterioration contrary to 1995, the boldface type then represents improvement. Data for each area are always calculated as simple arithmetic averages of the seven indicators from that area - see Table 1. Total is calculated as the arithmetic average of all 18 indicators. The Prague Region is in the first place of the overall rating, although it lags badly in quality of life. The Pardubický Regions is the only region that has improved during the time period in all areas. On the contrary, deterioration in all areas has been reported in the Jihočeský and Liberecký Regions. The Jihočeský, Jihomoravský and Plzeňský Regions have a very good position in the overall ranking, while the Ústecký, Karlovarský and Moravskoslezský Regions are placed at the bottom.

\section{Tab. 2: The level of regions in comparison to the average of the Czech Republic (part 1)}

\begin{tabular}{|c|c|c|c|c|c|c|c|c|}
\hline \multirow{2}{*}{ region } & \multicolumn{4}{|c|}{ MP } & \multicolumn{4}{|c|}{ GP } \\
\hline & 1995 & rank & 2011 & rank & 1995 & rank & 2011 & rank \\
\hline $\mathrm{CZ}$ & $100.00 \%$ & & $100.00 \%$ & & $100.00 \%$ & & $100.00 \%$ & \\
\hline CZ-P & $94.38 \%$ & & $90.20 \%$ & & $91.85 \%$ & & $89.87 \%$ & \\
\hline Prague & $145.16 \%$ & 1 & $178.09 \%$ & 1 & $162.26 \%$ & 1 & $175.93 \%$ & 1 \\
\hline Jihočeský & $117.96 \%$ & 2 & $95.77 \%$ & 5 & $102.99 \%$ & 3 & $89.41 \%$ & 5 \\
\hline Jihomoravský & $98.81 \%$ & 5 & $96.90 \%$ & 4 & $110.88 \%$ & 2 & $111.14 \%$ & 2 \\
\hline Karlovarský & $100.41 \%$ & 4 & $78.35 \%$ & 14 & $89.51 \%$ & 9 & $84.08 \%$ & 12 \\
\hline Královéhradecký & $98.05 \%$ & 7 & $86.02 \%$ & 8 & $89.49 \%$ & 10 & $86.88 \%$ & 9 \\
\hline Liberecký & $95.42 \%$ & 8 & $83.11 \%$ & 10 & $93.80 \%$ & 5 & $88.32 \%$ & 7 \\
\hline Moravskoslezský & $89.91 \%$ & 9 & $83.77 \%$ & 9 & $91.63 \%$ & 6 & $88.39 \%$ & 6 \\
\hline Olomoucký & $82.80 \%$ & 14 & $81.86 \%$ & 11 & $89.95 \%$ & 7 & $92.27 \%$ & 4 \\
\hline Pardubický & $89.15 \%$ & 11 & $89.06 \%$ & 6 & $85.36 \%$ & 11 & $85.76 \%$ & 10 \\
\hline Plzeňský & $111.70 \%$ & 3 & $98.42 \%$ & 3 & $98.61 \%$ & 4 & $93.56 \%$ & 3 \\
\hline Středočeský & $98.54 \%$ & 6 & $111.71 \%$ & 2 & $83.04 \%$ & 12 & $84.13 \%$ & 11 \\
\hline Ústecký & $86.78 \%$ & 13 & $79.57 \%$ & 13 & $89.87 \%$ & 8 & $88.00 \%$ & 8 \\
\hline Vysočina & $89.25 \%$ & 10 & $88.95 \%$ & 7 & $76.54 \%$ & 14 & $78.31 \%$ & 14 \\
\hline Zlínský & $87.98 \%$ & 12 & $81.78 \%$ & 12 & $81.23 \%$ & 13 & $81.63 \%$ & 13 \\
\hline \multirow{2}{*}{ region } & \multicolumn{4}{|c|}{ QL } & \multicolumn{4}{|c|}{ total } \\
\hline & 1995 & rank & 2011 & rank & 1995 & rank & 2011 & rank \\
\hline $\mathrm{CZ}$ & $100.00 \%$ & & $100.00 \%$ & & $100.00 \%$ & & $100.00 \%$ & \\
\hline CZ-P & $101.42 \%$ & & $101.65 \%$ & & $95.91 \%$ & & $94.29 \%$ & \\
\hline Prague & $90.83 \%$ & 12 & $92.22 \%$ & 12 & $132.39 \%$ & 1 & $146.29 \%$ & 1 \\
\hline Jihočeský & $157.86 \%$ & 2 & $144.31 \%$ & 3 & $126.26 \%$ & 2 & $112.36 \%$ & 4 \\
\hline Jihomoravský & $121.18 \%$ & 6 & $148.86 \%$ & 2 & $113.24 \%$ & 5 & $121.63 \%$ & 2 \\
\hline Karlovarský & $98.44 \%$ & 11 & $93.38 \%$ & 11 & $94.51 \%$ & 11 & $85.23 \%$ & 12 \\
\hline Královéhradecký & $126.49 \%$ & 4 & $125.02 \%$ & 6 & $107.03 \%$ & 6 & $101.82 \%$ & 7 \\
\hline Liberecký & $112.17 \%$ & 9 & $112.25 \%$ & 10 & $101.49 \%$ & 8 & $96.79 \%$ & 11 \\
\hline Moravskoslezský & $76.82 \%$ & 13 & $71.81 \%$ & 14 & $85.22 \%$ & 13 & $81.60 \%$ & 13 \\
\hline
\end{tabular}




\begin{tabular}{|c|c|c|c|c|c|c|c|c|}
\hline \multirow{2}{*}{ region } & \multicolumn{4}{|c|}{ QL } & \multicolumn{4}{|c|}{ total } \\
\hline & 1995 & rank & 2011 & rank & 1995 & rank & 2011 & rank \\
\hline Olomoucký & $122.67 \%$ & 5 & $128.41 \%$ & 5 & $101.85 \%$ & 7 & $103.80 \%$ & 6 \\
\hline Pardubický & $101.78 \%$ & 10 & $113.47 \%$ & 9 & $93.44 \%$ & 12 & $97.64 \%$ & 10 \\
\hline Plzeňský & $154.65 \%$ & 3 & $131.18 \%$ & 4 & $121.38 \%$ & 3 & $109.84 \%$ & 5 \\
\hline Středočeský & $113.40 \%$ & 8 & $116.36 \%$ & 8 & $96.94 \%$ & 10 & $101.31 \%$ & 8 \\
\hline Ústecký & $72.93 \%$ & 14 & $72.92 \%$ & 13 & $82.47 \%$ & 14 & $79.75 \%$ & 14 \\
\hline Vysočina & $181.44 \%$ & 1 & $161.15 \%$ & 1 & $120.23 \%$ & 4 & $112.78 \%$ & 3 \\
\hline Zlínský & $120.36 \%$ & 7 & $122.07 \%$ & 7 & $98.94 \%$ & 9 & $98.98 \%$ & 9 \\
\hline
\end{tabular}

Source: [9], [10], [11], [25], own calculations

It is also possible to determine the rank of regions based on their dynamics. In Table 3, the data of 1995 represent $100 \%$ and the order of regions is determined by the values from 2011 .

\section{Tab. 3: The rank of regions based on their dynamics}

\begin{tabular}{l|c|c|c|c|c|c|c|c}
\multirow{2}{*}{$1995=100 \%$} & \multicolumn{2}{|c|}{ MP } & \multicolumn{2}{c|}{ GP } & \multicolumn{2}{c|}{ QL } & \multicolumn{2}{c}{ Total } \\
\cline { 2 - 9 } & $\mathbf{2 0 1 1}$ & rank & $\mathbf{2 0 1 1}$ & rank & $\mathbf{2 0 1 1}$ & rank & $\mathbf{2 0 1 1}$ & rank \\
\hline CZ & $134.41 \%$ & & $159.89 \%$ & & $189.40 \%$ & & $160.44 \%$ & \\
\hline CZ-P & $129.48 \%$ & & $159.19 \%$ & & $189.25 \%$ & & $158.77 \%$ & \\
\hline Prague & $155.95 \%$ & 1 & $171.69 \%$ & 3 & $313.36 \%$ & 1 & $219.61 \%$ & 1 \\
\hline Jihočeský & $122.98 \%$ & 9 & $164.08 \%$ & 4 & $175.50 \%$ & 10 & $154.46 \%$ & 9 \\
\hline Jihomoravsḱ́ & $138.79 \%$ & 3 & $159.99 \%$ & 7 & $240.21 \%$ & 2 & $178.03 \%$ & 4 \\
\hline Karlovarský & $104.80 \%$ & 14 & $152.50 \%$ & 10 & $170.47 \%$ & 12 & $143.73 \%$ & 13 \\
\hline Královéhradecký & $121.28 \%$ & 11 & $156.71 \%$ & 9 & $186.68 \%$ & 8 & $154.65 \%$ & 8 \\
\hline Liberecký & $115.50 \%$ & 13 & $142.84 \%$ & 12 & $193.05 \%$ & 7 & $151.70 \%$ & 10 \\
\hline Moravskoslezskýy & $123.46 \%$ & 8 & $159.71 \%$ & 8 & $155.92 \%$ & 14 & $146.66 \%$ & 11 \\
\hline Olomoucký & $133.61 \%$ & 6 & $164.04 \%$ & 5 & $196.33 \%$ & 6 & $162.67 \%$ & 6 \\
\hline Pardubický & $138.27 \%$ & 4 & $178.41 \%$ & 2 & $224.11 \%$ & 3 & $179.72 \%$ & 3 \\
\hline Plzeňský & $116.23 \%$ & 12 & $149.61 \%$ & 11 & $158.54 \%$ & 13 & $143.47 \%$ & 14 \\
\hline Středočeský & $153.43 \%$ & 2 & $138.26 \%$ & 13 & $205.65 \%$ & 5 & $162.42 \%$ & 7 \\
\hline Ústecký & $122.33 \%$ & 10 & $164.04 \%$ & 6 & $219.29 \%$ & 4 & $170.63 \%$ & 5 \\
\hline Vysočina & $134.63 \%$ & 5 & $136.27 \%$ & 14 & $170.97 \%$ & 11 & $144.44 \%$ & 12 \\
\hline Zlínský & $124.00 \%$ & 7 & $259.47 \%$ & 1 & $183.11 \%$ & 9 & $196.18 \%$ & 2 \\
\hline
\end{tabular}

Source: [9], [10], [11], [25], own calculations

A comprehensive evaluation can be clearly made by using the individual regions' indicators of dynamics and level compared to the same indicators for CZ or CZ-P. The resulting data for the Total area are given in Figure 1.
The level in Figure 1 is calculated as the average of the initial and final values (or more precisely the values of 1995 and 2011) of the Total area. The dynamics is expressed as the average growth rate between the initial and 


\section{Ekonomie}

final value of the dynamics indicators in the area. This average is then related to the data for the $\mathrm{CZ}$, which were calculated in the same way. In both cases CZ represents $100 \%$ and its position in Figure 1 is shown by the black axes (the axes that appear less bold show the CZ-P). It is possible to create graphs of the MP, GP, QL areas this way.

According to Figure 1, the Prague region has the best results and is followed by the Jihomoravský region. Around the average of CZ there are the Olomoucký, Středočeský, Královehradecký and Liberecký Regions and the worst position is occupied by the Moravskoslezský and Karlovarský Regions. Other regions have at least either the high level or good dynamics. The point in the middle of dashed axes represents the aforementioned national average without Prague. The advantage of this chart is a clearly presented division of observed regions into four quadrants: growing rapidly, losing edge, increasing the loss and reducing the loss.

It is evident that the Moravskoslezský and Karlovarský regions are the most problematic ones in terms of Total (i.e. all observed areas) as compared to the average of $\mathrm{CZ}$ without Prague. Liberecký, Královehradecký, Plzeňský, Vysočina and Jihočeský Regions might become problematic in the future. The dynamics of other regions is above the average.

\section{Fig. 1: The dynamics and level of regions in 1995-2011 in Total}

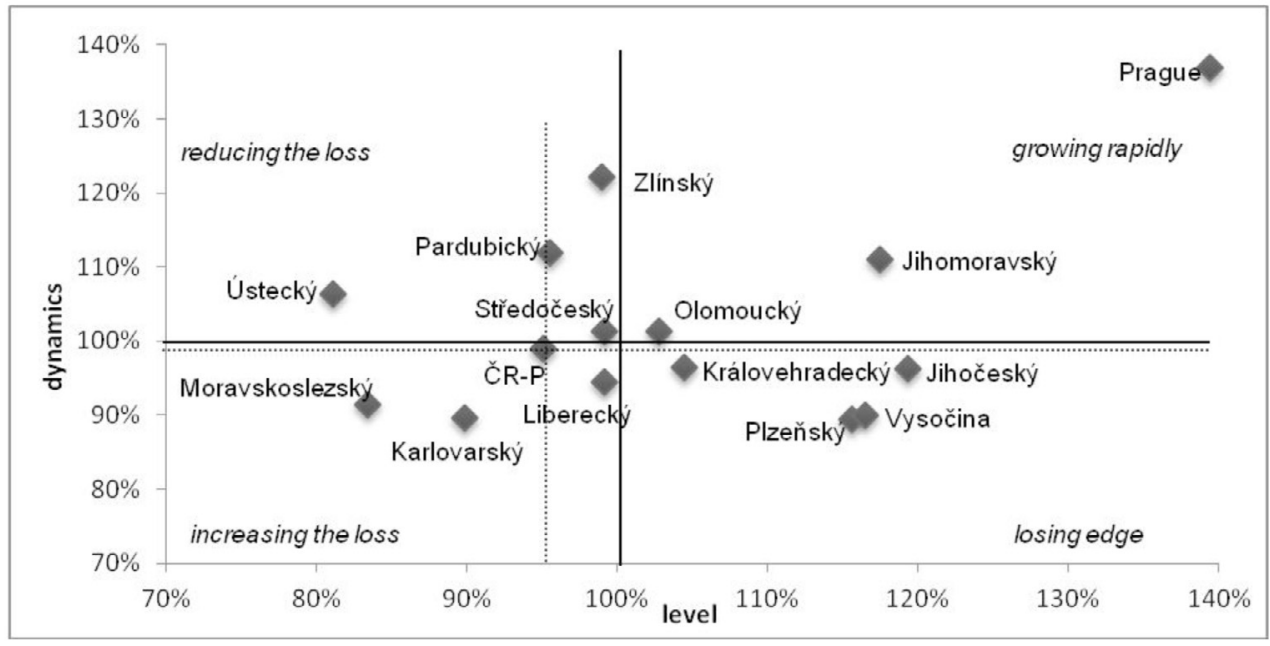

Source: [9], [10], [11], [25], own calculations

The above-collected data can be used for the distribution of regions into clusters. This method divides regions into several groups with common characteristics that can be further independently evaluated and the movements of regions among clusters over the years can be compared. For details of this analysis and its results see [37].

\section{5. $\beta$-convergence}

The above-mentioned fundamental differences

- disparities - between regions are obvious from the analysis, especially between the Prague Region and the others. The question is whether these differences became larger or smaller over time, i.e. whether the regions diverge or converge. To better understand this issue, it is useful to define the concept of regional disparity first and indicate its most frequent causes. Even different factors causing regional disparities may determine whether the region will rather converge or diverge more in time. The word disparity, as well as regional competitiveness, has many possible definitions. 
Disparity can be generally defined as "dissimilarity or inequality of signs, phenomena or processes having unique geographical position and occurring at least in two entities of that spatial structure" [16, p. 8].

There are various factors that may cause the different development of regions. It could be the geographic location of the region, its natural conditions, transport infrastructure, investments and funds directed to the region, institutional factors or a political decision. Hučka et al. [16] states that the fundamental factors of disparities are the following: "equipment of production factors, natural conditions, natural physical-geographical advantages, economic structure and socio-cultural and institutional factors" [16, p. 15]. In terms of natural conditions, different development may be caused, for example, by the existence of large deposits of mineral resources and more suitable conditions for agriculture in comparison with other regions. From this fact the environmental quality will also develop subsequently. With regard to the geographic location, the distance to foreign advanced regions [40] or the distance to other economic centers are important (especially the distance to Prague in the CZ). We can discuss whether the abovementioned causes can influence the development of regions and if so to what extent, but this is not the aim of this section. The intention is simply to determine whether the region in the $C Z$ tends, while assuming these various causes, rather to diverge or converge over time.

There are many theories of regional development which can basically be classified into two types, namely the theory of convergence and the theory of divergence. Convergence theories or theories of regional balance say that regions converge over time, so that interregional disparities disappear. On the other hand, divergence theories or theories of regional imbalances assume that regional disparities will become deeper and regions will diverge even more [6]. It is obvious that the development of regions and hence their convergence/ /divergence is to some extent affected by the development of the state itself. According to Terrasi [38] the process of regional convergence is not conditioned only by the stage of national development, but also by its characteristics. The national development can vary greatly from state to state, depending on the geographic location, time in which the process began, development or the intensity, product specialization, regional structure, etc. Another fact that may influence the development of regions is whether those are located near large cities. The study on this topic was conducted by Hammond [15], who dealt with divergence of metropolises from neighboring regions and who has arrived at an interesting conclusion. An irrefutable fact is that metropolises tend to diverge more and more over time, but their neighboring non-metropolitan regions have a tendency to converge more than other nonmetropolitan regions that are not adjacent to any metropolis.

Regarding the actual measurement of convergence/divergence of regions, most authors perform their calculations using only the basic macroeconomic indicators for regions, in particular, only GDP per capita (as exemplified by the neo-classical Barro, Sala-iMartin and the above mentioned Terrasi and Hammond, etc.).

Many authors deal with the subject of convergence and usually two types of convergence between different economies can be defined; these are absolute convergence and conditional convergence. Absolute convergence implies that countries or regions with lower initial values of the capital/labor share show a higher growth rate of output per capita and tend to catch up with and converge to the countries or regions with a higher capital/labor share. The assumption is, however, that economies are similar in structure; they have the same parameters, and thus the same steady state. Closer to reality is the concept of conditional convergence, where the condition that all economies have the same parameters and the same steady state does not apply. This model does not predict convergence in all cases, because there may be a situation where the more developed economies are growing faster than the less developed ones. That is because "the neoclassical model does predict that each economy converges to its own steady state and the speed of this convergence relates inversely to the distance from the steady state" $[4$, p. 29]. So, if a more developed economy is more distanced from its steady state than a less developed one, it grows faster and the differences among them will deepen. Thus the 
convergence is conditioned by determinants of the steady state. Absolute convergence, which suggests that poor countries tend to show higher growth rate of output per capita than the rich ones, then corresponds to the concept of $\beta$-convergence. This convergence can be defined by the following equation [4, p. 384]:

$$
\log \left(\frac{y_{i, t+1}}{y_{i, t}}\right)=\alpha+\left(e^{-\beta}-1\right) \cdot \log y_{i, t}+\varepsilon_{i, t},
$$

where $y$ is the monitored indicator (usually real GDP), $i$ is a country or region and $t$ the period of time. Assumptions of the normal distribution with the zero mean value and constant variance are imposed on random variable $\varepsilon_{i, t}$. It also has to be independent of its past values and other variables in the model. The left side of the equation can be interpreted as the growth rate of indicator $y_{i}$ and the aforementioned formula implies that this growth depends on the parameter $\alpha$ and parameter $\beta . \alpha$ expresses the steady state level and $\beta$ expresses the value by which the gap between the steady state and reality has diminished during the period. $\beta$ is the speed of convergence and if the value is positive, it means that the economy converges and if negative, it means that the gap grows and on the contrary the economy diverges.

The concept of conditional convergence corresponds to the concept of $\sigma$-convergence, which occurs when the variance of indicator $y_{i}$ decreases over time. Although this concept is defined for income or product, it will be used for the analysis of our data. This also implies that "the convergence of the first type (poor countries tend to grow faster than rich ones) tends to generate the convergence of the second type (reduced dispersion of income or product per capita), but this process is offset by new random disturbances that tend to increase dispersion" [4, p. 383]. $\beta$-convergence is a necessary but not sufficient condition of $\sigma$-convergence.

The application of both concepts of convergence to the data above is based on the idea that regional competitiveness (their level) tends to converge. There are two reasons for this:

1) structural parameters of different regions are the same, not only in terms of aggregate production functions as in case of the neo-classical models, but due to the absolute openness of regions to each other (this fact itself leads to a theoretically infinite speed of convergence) and also due to social, cultural and linguistic homogeneity of regions within one country,

2) bearers of economic policy including the EU seek to mitigate regional disparities.

Statistical analysis of $\beta$ and $\sigma$-convergence/divergence was performed with the logarithm level data of each region in each year in the areas of MP, GP, QL and in Total (T). To complement these, the indicator of real GDP per capita was also used. The raw data for the Total area are shown in Figure 2. These are standardized data that compare the regional level with the national average (value 0). The national average is then understood as a steady state to which the regions should converge. The horizontal axis represents the level of $\log y_{i, t}$ and vertical axis represents the growth rate $\log y_{i, t+1}-\log y_{i, t}$ Similar graphs can be created for other areas.

The graph (Fig. 2) represents data for all regions and all years. These data can be imagined as a matrix whose elements are $\log y_{i, t}$, where $i$ is an index indicating the region and $t$ is an index indicating the period $t \in\langle 1995 ; 2011\rangle$. The values measured on the horizontal axis correspond exactly to this matrix and thus represent the logarithm of the relative level of the region in relation to the $C Z$ average. The values measured on the vertical axis are then calculated as the difference between two adjacent elements in the row in this matrix, i.e. $\log y_{i, t+1}-\log y_{i, t}$ and correspond to the logarithmic approximation of the growth rate.

Sub-matrices in which the above-mentioned regression model is statistically significant were sought in data (matrices) for all areas (MP, GP, $\mathrm{QL}, \mathrm{T}$ and GDP). The minimum dimension of a sub-matrix was limited to two regions and two consecutive periods, the maximum dimension is given by the whole matrix consisting of 14 regions and 17 consecutive years. The brutal computing power was simply used, which MATLAB enables very easily. For each area (MP, GP, QL, T and GDP) 1,965,280 regressions were carried out; this number is determined by combinations of different regions and different time intervals. The obtained results were tested for statistical significance of the whole regression model (P-value of F-test), then the statistical significance of the regression line (P-value of T-statistics). Normality of residues 


\section{Fig. 2: Display of convergence/divergence by using raw data in Total}

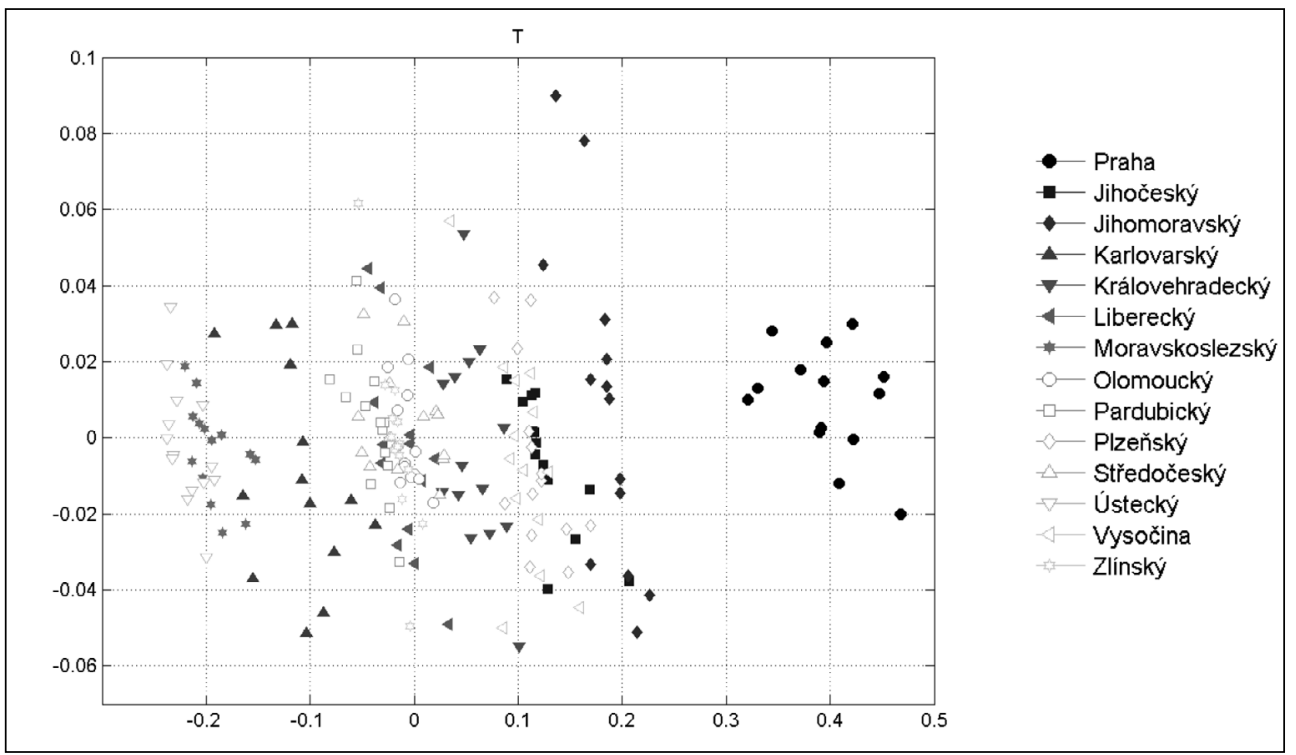

Source: [9], [10], [11], own calculations

was assessed by the Kolmogorov-Smirnov test and the Jarque-Bera test. Since there are no time series (regions do not have a fixed order and can be randomly permuted), testing of autocorrelation of residues is not significant, yet they were tested, although it significantly slowed down the computation. We have always managed to rank the regions in such a way so that the resulting P-value of Durbin-Watson statistics could reflect uncorrelated data. The results therefore meet all the necessary statistical criteria.

The obtained results were further subjected to a more rigorous evaluation. Only regressions with adjusted coefficient of determination $R_{A D j}^{2}$ higher than $50 \%$ were used for the interpretation. Furthermore, relatively small sub-matrices with less than 9 elements were excluded and only larger sub-matrices, with at least 9 elements, were interpreted. We believe that the statistical significance in such small sub-matrices would be a matter of chance rather than a real statistical relationship. Specifically, the 4-element submatrices had no statistically significant regression. There were 50 statistically significant regressions in 6-element sub-matrices and 48 regressions in 8-element sub-matrices, mostly with a very high coefficient of determination, which we ascribe to a chance and thus we do not interpret it. The negative slope of the regression line is then $\beta$-convergence and positive slope is $\beta$-divergence. The relationship with at least $+10 \%$ speed of convergence was considered as convergence and the relationship with maximum of $-10 \%$ speed of convergence was considered as divergence. The number of identified regressions is shown in Table 4.

\section{Tab. 4: Number of regressions}

\begin{tabular}{l|c|c} 
Area & $\beta$-convergence & $\beta$-divergence \\
\hline MP & 62 & 6 \\
\hline GP & 250 & 3 \\
\hline $\mathrm{QL}$ & 81 & 50 \\
\hline $\mathrm{T}$ & 21 & 15 \\
\hline $\mathrm{GDP}$ & 27 & 49 \\
\hline
\end{tabular}

Source: own calculations

At first glance it is obvious that out of the total number of performed regressions, there 


\section{Ekonomie}

are only few statistically significant. This suggests that the regions due to the selected metrics remain persistent in the discrepancies. However, this says nothing about the relations between individual regions. Therefore, we performed a detailed analysis of the achieved results. The main question was how to clearly and simply interpret these 441 convergences and 123 divergences. Therefore, we chose a graphical method that makes it possible to capture i) a combination of regions and years that have the appropriate relationship for the area, and ii) the intensity of relationship measured by the speed of convergence/ /divergence. All results are naturally influenced by the arbitrary choice of criteria for "significant" regression relationships, however, we believe that they still have explanatory power.

The following Figure No. 3 shows how long (measured by the number of years) as well as in what intensity (measured by the speed of convergence) each pair of corresponding regions converged. The number of occurrence of the two regions in regressions identified according to the above criteria was multiplied by the number of years of convergent/divergent relationship and then multiplied by the speed of convergence/divergence. The darkest color means the "strongest" calculated convergence/ /divergence. As the chart of colored matrix of regions does not give information about the periods in which these relations occurred, the colored timeline is attached. Here the color for each year is given by multiplying (product) the number of regions and the speed of convergence/divergence. This allows us to identify the years in a given area when the major convergence/divergence occurred.

All the graphs of convergence show absolute absence of Prague and, on the contrary, almost absolute presence of the Královéhradecký, Liberecký, Olomoucký, Pardubický and Plzeňský Regions. The absence of Prague was anticipated since this region has a too high Macroeconomic Performance in all monitored periods. In the area of macroeconomic performance, the Královéhradecký, Plzeňský and Zlínský Regions mostly participate. The Plzeňský Region also participates in the processes of convergence in the area of Growth Potential, but due to its downturn in this area the worse regions are catching up with it. On the contrary, neither Prague participates in the convergence nor the Jihomoravský (it is also significantly above the average) and Vysočina Regions (below the average). In the area of Quality of Life in addition to Prague the Moravskoslezský and Ústecký Regions did not participate in the process of convergence (they are the worst ones over the whole period, compare Table 2). Regarding the Total area, Prague did not take part in the convergence because of its permanently and considerably above-the-average position and the Moravskoslezský and Ústecký Regions did not take part in convergence either due to their permanently and considerably below-theaverage position. The GDP graph shows the absolute distance of Prague in all the observed periods, and hence Prague could not appear in any statistically significant regression. The Olomoucký Region did not participate in the convergence either because of its size and growth rate of GDP. From the perspective of individual years we do not see any systematic (across regions) concentration of convergence at the beginning or end of the period in the graphs.

For the sake of completeness we should add that the colors in the charts are not standardized in the same way for the simple reason of their lucidity. "Values" of the darkest colors in all matrix charts in comparison to the graph of T convergence (value 1 ) is shown in the following Table 5. Similarly, colors of graphs representing individual years are not standardized.

Tab. 5: $\begin{aligned} & \text { Values of } \\
& \beta \text {-convergence/divergence }\end{aligned}$
\begin{tabular}{l|c|c} 
Colour intensity & $\beta$-convergence & $\beta$-divergence \\
\hline MP & 4.11 & 0.36 \\
\hline GP & 20.38 & 0.41 \\
\hline QL & 5.09 & 3.17 \\
\hline$T$ & 1.00 & 0.64 \\
\hline GDP & 2.72 & 1.75 \\
\hline \multicolumn{3}{|c}{ Source: own calculations }
\end{tabular}

The figures below (Fig. 4) show results for ascending regression lines, that is for divergence. The total number of divergences is more than three times smaller than the number of convergences. In the area of Macroeconomic Performance it is obvious that some 


\section{Fig. 3: Time and intensity of convergence}

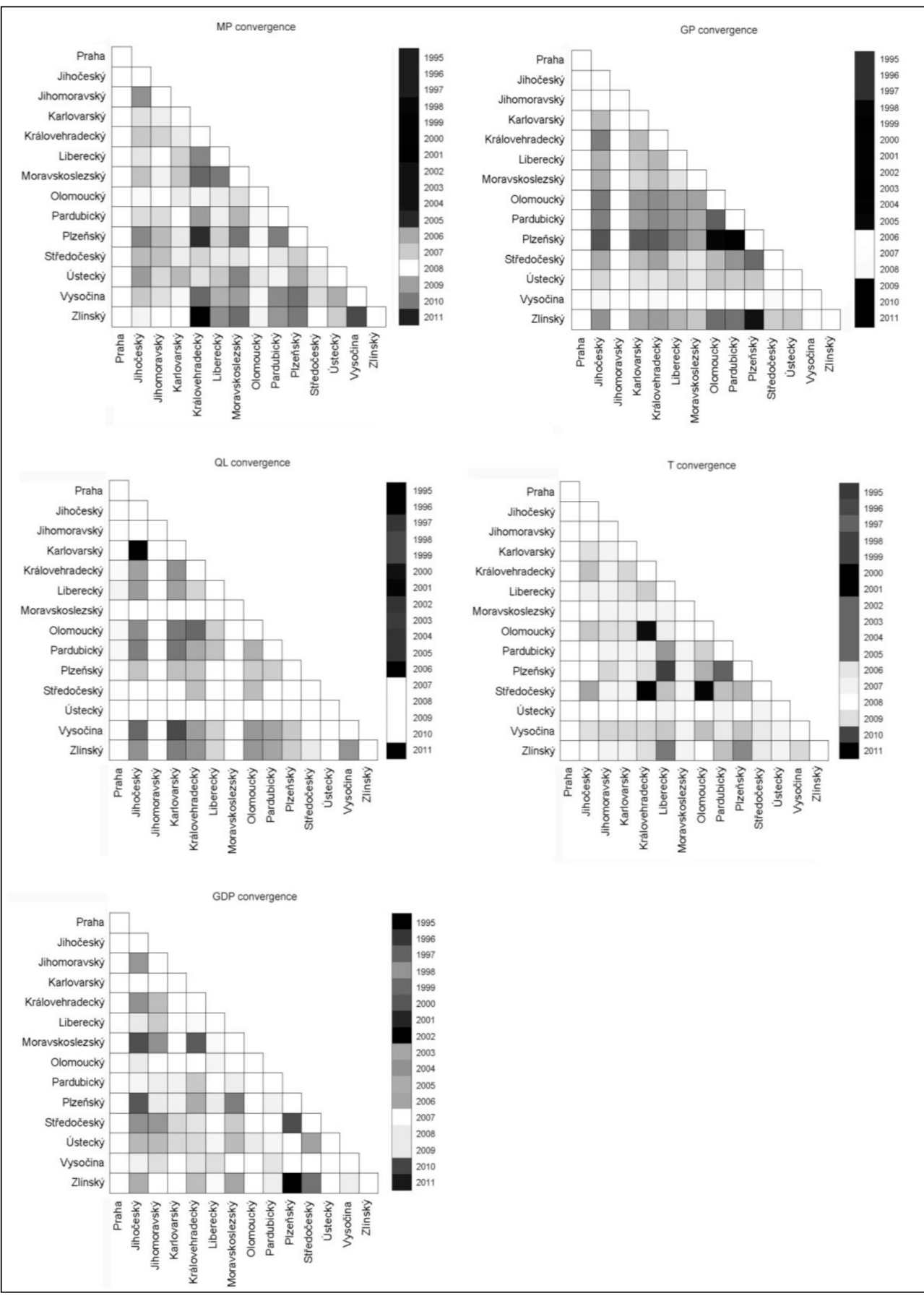

Source: [9], [10], [11], own calculations 


\section{Ekonomie}

\section{Fig. 4: Time and intensity of divergence}
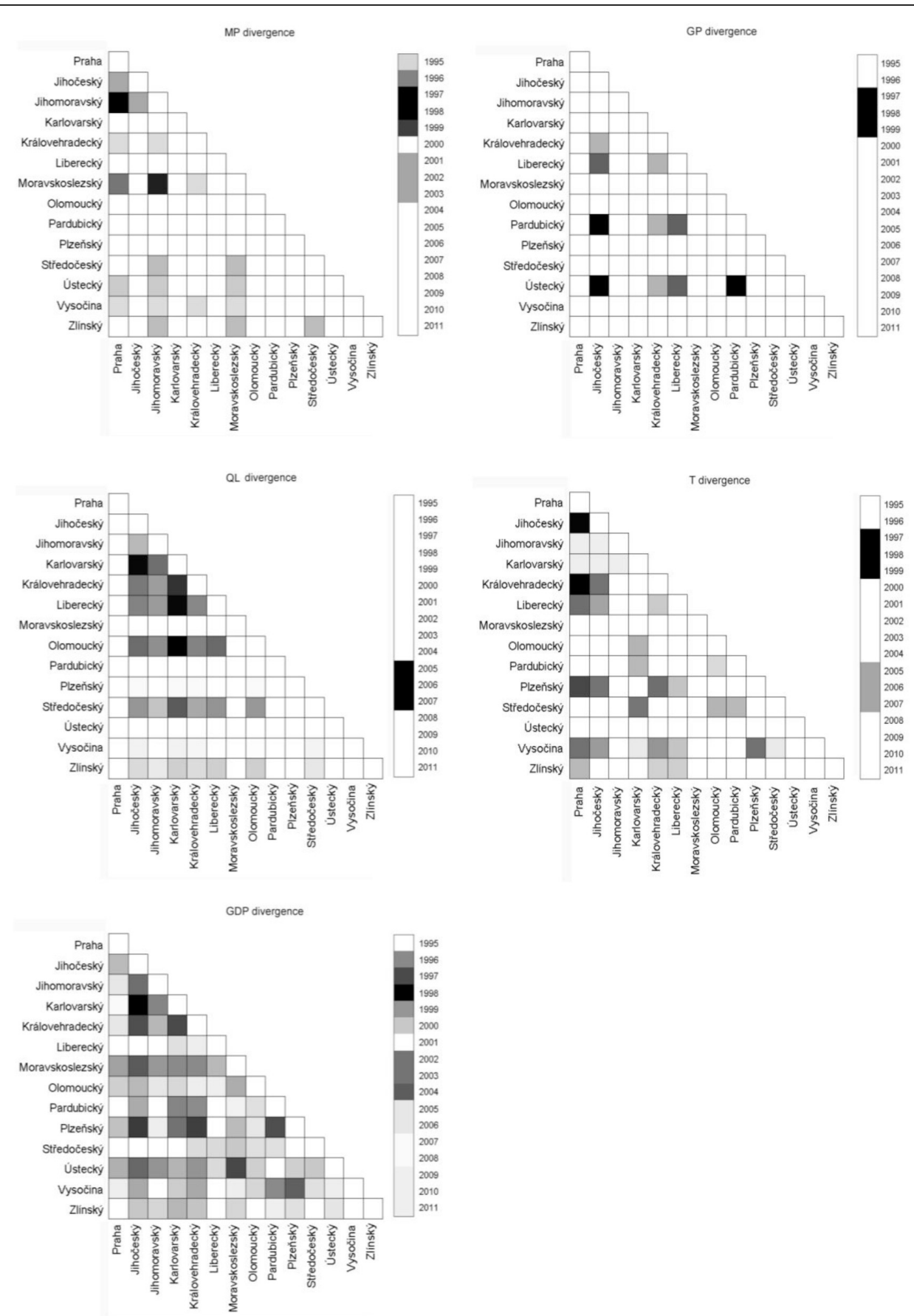
of the growing regression lines also "hit" the Prague Region. Also the Jihomoravský and Moravskoslezský Regions participate more in the process of divergence, but other regions participate only rarely. There were only 3 statistically significant divergences in the area of Growth Potential, which is the lowest number of all. Mostly the Jihočeský, Pardubický and Ústecký Regions diverged; as regards the period, the divergence is concentrated between 1997 and 1999. In the area of Quality of Life, Prague, the Moravskoslezský, Pardubický, Plzeňský and Ústecký Regions did not diverge. In terms of Total area, the Moravskoslezský and Ústecký Regions did not diverge at all, because they are permanently the worst ones. The last graph shows that especially in 1998 and 2004 there was a divergence in GDP in all regions, with partial exception of the Středočeský and Liberecký Regions. Similarly to the convergence, also in the case of divergence we cannot find any systematic concentration of this relationship in some specific years.

Let us briefly note $\sigma$-convergence. This convergence, as mentioned above, consists in reducing the variance of observed variables over time. The measurements were performed by linear regression estimate of the time series of variances. If the slope of the regression line is negative, it means that the variance decreases with time and therefore it is $\sigma$-convergence. The opposite situation is called $\sigma$-divergence. The number of estimated data is equal to the length of the period and hence the majority of results were statistically insignificant. Of the total number of statistically significant regression models, which was 9,8 match the $\beta$-convergence, in 4 cases in the GDP area, three times in the MP and once in Total area. On the contrary, the divergence has been demonstrated only in one case in the MP area. But it must be said that compared to $\beta$-convergence there are only a few cases and we can say that there are practically constant variances of the monitored parameters over the whole period among all regions and apart from the $\beta$-convergence we can also exclude divergence.

\section{Conclusion}

There are many methods which could be used for evaluation of competitiveness; some are more useful than others. Quantification of competitiveness on the basis of the presented method gives interesting results, which could be used to analyze convergence and divergence of regions. The quantification is carried out for the period of 17 years, as some data before 1995 were not observed by the Statistical Office, and some ceased to be observed starting in 2010. However, all authors who deal with the issue of regional competitiveness has to face the problem of lack of data. Nevertheless, our analyses were made on the basis of a large number of indicators and data, especially in comparison with other studies, which often use only the basic macroeconomic indicators. Nearly 4,200 indicators were either taken from the regional statistics directly or were calculated from a large number of other indicators.

In the last part of this article the analysis of the extent of convergence/divergence of regions was appropriate. This analysis was based on the data from previous research of competitiveness and brought interesting results showing the different trends in the development of Prague, the Moravskoslezský and Ústecký Regions. The reason why they did not participate in the process of $\beta$-convergence or $\beta$-divergence is their diametrical difference from the remaining regions. Prague usually (meant by area used) has a much better position, while the other two regions are usually substantially below the average. However, no statistically significant $\beta$-convergence or $\beta$-divergence across the higher number of regions and lasting for a longer period were identified. Further the analysis of the variance in individual areas eliminated $\sigma$-divergence, which was identified only in one case, and almost eliminated $\sigma$-convergence, which occurred only in 8 cases. Thus the results of the analysis of convergence/ /divergence confirm our expectations that relatively stable differences among individual regions remain. Therefore, it can only be said that the individual regions exhibit persistent discrepancies and the region which differs markedly from the rest is the Prague Region.

The continuous political effort of the EU to reduce interregional discrepancies enabled the Czech Republic to use nearly $€ 26.6$ billion in the $2007-2013$ period [13]. This is $2.2-2.5 \%$ of Czech GDP every year, which is a very large 


\section{Ekonomie}

amount of money, but our study does not show the positive effect of it. The aim of our study was not the evaluation of efficiency of regional policy, but it was only aimed at the comprehensive description of the reality. However, to evaluate the fruitfulness of regional policy objectively, some ingredients are still missing. Firstly, we do not know the benchmark data describing the development without regional policy, which is not typical only of regional policy, but it is a general phenomenon in economic policy evaluation. Secondly, the same problems with drawing money from EU funds occured. And thirdly, our analysis of convergence/ /divergence is performed only in terms of indicators used to analyze competitiveness, which may not fully correspond to the reality, where the discrepancies may become more or less evident in other areas or indicators.

Nevertheless, we believe that despite the objective deficiencies in the data used, an understanding reader will find "his/her own region" in the presented results and intuitively conduct an evaluation of its position himself/herself. That is why we have refrained from unnecessary extensive comments on the individual regions.

\section{References}

[1] AIGINGER, K. Competitiveness: From a Dangerous Obsession to a Welfare Creating Ability with Positive Externalities. Journal of Industry, Competition and Trade. 2006, Vol. 6, Iss. 2, pp. 161-177. ISSN 1566-1679.

[2] ANNONI, P., DIJKSTRA, L. EU Regional Competitiveness Index RCl 2013 [online]. Publications Office of the European Union, 2013 [cit. 2014-02-21]. Available from: http://publications. jrc.ec.europa.eu/repository/handle/111111111/29832. ISSN 1831-9424.

[3] ANNONI, P., KOZOVSKA, K. EU Regional Competitiveness Index RCI 2010 [online]. Publications Office of the European Union, 2010 [cit. 2014-02-21]. Available from: http://publications. jrc.ec.europa.eu/repository/handle/111111111/13666. ISSN 1018-5593.

[4] BARRO, R. J., SALA-I-MARTIN, X. Economic Growth. New York: McGraw-Hill, 1995. ISBN 0-262-02459-4.

[5] BENEŠ, M. Konkurenceschopnost a konkurenční výhoda [online]. Mendelova univerzita Brno, 2006. Working Paper 5/2006 [cit. 2013-02-22].
39 p. (PDF). Available from: http://is.muni.cz/do/ 1456/soubory/oddeleni/centrum/papers/wp200605.pdf. ISSN 1801-4496.

[6] BLAŽEK, J., UHLÍŘ, D. Teorie regionálního rozvoje. Praha: Karolinum, 2002. ISBN 80-246-0384-5. [7] BOSCHMA, R. Evolutionary economic geography and its implications for regional innovation policy. Papers in Evolutionary Economic Geography [online]. Utrecht: Utrecht University, 2009. No. 09.12 [cit. 2014-02-21]. 34 p. (PDF). Available from: http://econ.geo.uu.nl/peeg/peeg 0912.pdf.

[8] COHEN, S.S. Speaking Freely. Foreign Affairs. 1994, Vol. 73, Iss. 4, pp. 195-197. ISSN 0015-7120. [9] ČESKÝ HYDROMETEOROLOGICKÝ ÚSTAV. Emisní bilance $\check{C} R$ [online]. Praha: Český hydrometeorologický ústav, 2013 [cit. 2013-0204]. Available from: http://portal.chmi.cz/files/ portal/docs/uoco/oez/emisnibilance_CZ.html.

[10] ČESKÝ STATISTICKÝ ÚŘAD. Krajské ročenky 2012 [online]. Praha: Český statistický úřad, 2013 [cit. 2013-02-04]. Available from: http://www.czso.cz/csu/edicniplan.nsf/aktual/ep-1.

[11] ČESKÝ STATISTICKÝ ÚŘAD. Regionální účty [online]. Praha: Český statistický úřad, 2013 [cit. 2013-02-04]. Available from: http://apl.czso.cz/ pll/rocenka/rocenka.indexnu_reg.

[12] EUROPEAN COMMISSION. Sixth Periodic Report on the Social and Economic Situation of Regions in the EU [online]. Brussels: European Commission, 1999 [cit. 2013-02-21]. Available from: http://aei.pitt.edu/5712/.

[13] EUROPEAN COMMISSION. Regionální politika - inforegio [online]. Brussels: European Commission, 2013 [cit. 2014-02-21]. Available from: http://ec.europa.eu/regional_policy/thefunds/ funding/index_cs.cfm.

[14] GARDINER, B., MARTIN, R., TYLER, P. Competitiveness, Productivity and Economic Growth across the European Regions. European Regional Science Association conference papers [online]. 2004 [cit. 2014-02-21]. 37 p. (PDF). Available from: http://www-sre.wu-wien.ac.at/ersa/ ersaconfs/ersa04/PDF/333.pdf.

[15] HAMMOND, G. Metropolitan/non-metropolitan divergence: A Spatial Markov chain approach. Papers in regional science [online]. 2004, Vol. 83, Iss. 3 [cit. 2013-02-04], pp. 543-563. Available from: http://www.springerlink.com/content/xabw 2b2pc21u68tm/. ISSN 1056-8190.

[16] HUČKA, M., KUTSCHERAUER, A., TOMÁNEK, P. Metodologická východiska zkoumání 
regionálních disparit. Regionální disparity [online]. 2008, Iss. 2 [cit. 2013-03-08]. Available from: http://disparity.vsb.cz/cz/elektronicky-casopis/. ISSN 1802-9450.

[17] JEŽEK, J. Městský marketing - koncepty, aplikace, kritická analýza. Ekonomický časopis. 2011, Vol. 59, Iss. 3, pp. 243-258. ISSN 0013-3035. [18] KADEŘÁBKOVÁ, A. Kvalitativně založená konkurenční výhoda ČR v mezinárodním srovnání. WP 2/2006. CES VŠEM, 2006. ISSN 1801-2728.

[19] KADEŘÁBKOVÁ, A. Analýza konkurenceschopnosti ČR v mezinárodním srovnání. In Sborník z mezinárodní vědecké konference Globalizace versus regionalismus. Liberec: Technická univerzita v Liberci, 2006. pp. 135-146. ISBN 80-7372-088-4.

[20] KAHOUN, J. Ukazatele regionální konkurenceschopnosti v České republice [online]. CES VŠEM, 2007. WP 5/2007 [cit. 2013-08-15]. 37 p. (PDF). Available from: http://www.vsem.cz/ data/data/ces-soubory/working-paper/gf WPNo507.pdf.

[21] KITSON, M., MARTIN, R., TYLER, P. Regional Competitiveness: An Elusive yet Key Concept? Regional Studies. 2004, Vol. 38, Iss. 9, pp. 991-999. ISSN 0034-3404.

[22] KRUGMAN, P. The Age of Diminished Expectations. Cambridge (MA): MIT Press, 1990. ISBN 978-0262611343.

[23] KRUGMAN, P. Competitiveness: a dangerous obsession. Foreign Affairs. 1994, Vol. 73, Iss. 2, pp. 28-44. ISSN 0015-7120.

[24] KRUGMAN, P. Proving My Point. Foreign Affairs. 1994, Vol. 73, Iss. 4, pp. 198-203. ISSN 0015-7120.

[25] MARTINČíK, D. Ekonomicko-sociální úroveň krajů - komplexní srovnávací analýza. $E+M$ Ekonomie a Management. 2008, Vol. 11, Iss. 1, pp. 14-25. ISSN 1212-3609.

[26] NEVIMA, J. Ekonometrický model konkurenceschopnosti. In Sborník př́spěvků z VIII. mezinárodní konference studentů doktorských studijnich programů IMEA 2008 [CD-ROM]. Liberec: Technická univerzita v Liberci, 2008. pp. 505-511. ISBN 978-80-7372-335-4.

[27] PORTER, M.E. The Competitive Advantage of Nations. New York: Free Press, MacMillan, 1990. ISBN 978-0684841472.

[28] PORTER, M.E., KETELS, C.H.M. UK Competitiveness: Moving to the Next Stage [online]. London: Department of Trade and Industry, 2003. DTI Economics Paper 3 [cit. 2014-02-21]. 60 p. (PDF). Available from: www.bis.gov.uk/files/file14771.pdf.

[29] PRESTOWITZ, C.V. Playing to Win. Foreign Affairs. 1994, Vol. 73, Iss. 4, pp. 186-189. ISSN 0015-7120.

[30] SCHARPING, R. Rule-Based Competition. Foreign Affairs. 1994, Vol. 73, Iss. 4, pp. 191-195. ISSN 0015-7120.

[31] SKOKAN, K. Konkurenceschopnost, inovace a klastry v regionálním rozvoji. Ostrava: Repropis, 2004. 159 s. ISBN 80-7329-059-6.

[32] SLANÝ, A. et al. Konkurenceschopnost české ekonomiky. Brno: Masarykova univerzita, 2006. ISBN 80-210-4157-9.

[33] STANÍČKOVÁ, M., POLEDNÍKOVÁ, E., SKOKAN, K. Konkurenceschopnost a soudržnost v zemích V4 po Lisabonské strategii. Současná Evropa. 2011, Iss. 1, pp. 115-137. ISSN 1804-1280. [34] STEIL, B. Careless Arithmetic. Foreign Affairs. Vol. 73, Iss. 4, pp. 197-197. ISSN 0015-7120.

[35] STORPER, M. The Regional World: Territorial Development in a Global Economy. New York: Guilford Press, 1997. ISBN 978-1572303157.

[36] SVATOŠOVÁ, L., BOHÁČKOVÁ, I. Metodologické prǐstupy $k$ hodnocení regionálních disparit. XV. mezinárodní kolokvium o regionálních vědách. Brno 2012, pp. 11-28. ISBN 978-80-2105875-0.

[37] ŠLEHOFEROVÁ, M. Využití shlukové analýzy při hodnocení ekonomicko-sociální úrovně regionů. In The $13^{\text {th }}$ Conference of Postgraduate Students and Young Scientists in Informatics, Management, Economics and Administration IMEA 2013 (Conference Proceedings) [CD-ROM] Pardubice: University of Pardubice, 2013. pp. 418424. ISBN 978-80-7395-696-7.

[38] TERRASI, M. Convergence and divergence across Italian regions. The annals of Regional Science. 1999, Vol. 33, Iss. 4, pp. 491-510. ISSN 0570-1864.

[39] THUROW, L.C. Microchips, Not Potato Chips. Foreign Affairs. 1994, Vol. 73, Iss. 4, pp. 189-191. ISSN 0015-7120.

[40] TVRDOŇ, M. Identifikace determinant regionálního vývoje v České republice. Regionální disparity [online]. 2008, Iss. 2 [cit. 2013-04-07], pp. 62-71. Available from: http://disparity.idealnihosting. cz/dokumenty2/RD_0802.pdf. ISSN 1802-9450.

[41] TYSON, L.A. Who's Bashing Whom? Trade Conflict in High-Technology Industries. 1st ed. Institute for International Economics, 1992. 352 p. ISBN 978-0881321067. 


\section{Ekonomie}

[42] VITURKA, M. Konkurenceschopnost regionů a možnosti jejího hodnocení. Politická ekonomie. 2007, Vol. 55, Iss. 5, pp. 637-658. ISSN 0032-3233. [43] ŽIŽKA, M. Methodology of Assessment of Disparities on Municipality Level as a Part of Territorial Planning. In KOCOUREK, A. (Ed.). Proceedings of the 10th International Conference Liberec Economic Forum 2011. pp. 614-622. ISBN 978-80-7372-755-0.
JUDr. Ing. David Martinčík

University of West Bohemia Faculty of Economics Department of Economics and Quantitative Methods martinci@kem.zcu.cz

Ing. Marta Šlehoferová University of West Bohemia Faculty of Economics Department of Geography msleh@kge.zcu.cz 


\section{Abstract}

\section{COMPETITIVENESS AND CONVERGENCE OF CZECH REGIONS: PERSISTENCE OF DISCREPANCIES \\ David Martinčík, Marta Šlehoferová}

The article provides an extensive analysis of the development of regional competitiveness in the Czech Republic over time. At first the attention is paid to the meaning of "regional competitiveness" and to the evaluation of proposed methods to quantify it. After that the quantification of regional competitiveness is made according to the chosen method, which is based on a large number of indicators and then these indicators are summarized into three areas: Macroeconomic Performance, Growth Potential and Quality of Life. More than 4,200 figures represent eighteen indicators of fourteen regions during the time period of seventeen years and describe the level of regions from the viewpoint of various aspects. The ranking of individual regions in the three areas mentioned above is compiled on the basis of the selected measurement method of competitiveness. The level and dynamics of regions were in conformity with the expected results: Prague is the best region, followed by Jihomoravský and Jihočeský Regions and, on the contrary, the Ústecký and especially Moravskoslezský and Karlovarský Regions are the worst ones. Therefore, the convergence/divergence analysis was conducted to provide detailed knowledge of this phenomenon. The concept of $\beta$-convergence and $\sigma$-convergence was applied to our data and the sets of regions which converge or diverge over some period of time were searched for. Although some of these sets exist, it is not possible to say that the convergence or divergence is a strong process typical of the majority of regions. On the contrary, the discrepancies among regions in the Czech Republic are persistent.

Key Words: Region, regional competitiveness, measurement of regional competitiveness, $\beta$-convergence, $\sigma$-convergence.

JEL Classification: O18, R11, C38, C21.

DOI: 10.15240/tul/001/2014-2-002 